\title{
RESULTS OF FUNCTIONING OF PUBLIC UNIVERSITIES: ESTABLISHING A SET OF RATIOS PROVIDING RELIABLE MANAGEMENT INFORMATION BASED ON DATA DERIVED FROM AN ENTITY'S REPORTS
}

The aim of the study is to define a set of ratios, enabling multidimensional assessment of the activity of public universities as units of the public finance sector, in order to improve the efficiency of their management. The selection of appropriate ratios, which are also highly reliable in relation to occurring phenomena and processes, becomes a useful management tool. Hence, the content of the study includes a comprehensive measurement of a university's results. Empirical research was conducted at a deliberately selected multi-disciplinary university, i.e. an entity conducting research and didactic activities in many fields of science. The empirical material was collected using information derived from financial statements and analytical information from the accounting books of the analyzed entity. The study covered the years from 2015 to 2019. The conducted empirical research provided evidence in the light of which the developed set of ratios has a high management usefulness, as it allowed to assess the state of processes taking place in the examined unit.

Key words: efficiency of universities, entrepreneurship, education, research, reporting, public sector

JEL Classification: I23; M41; M49

\section{Introduction}

Many public sector entities do not function in order to generate a financial surplus but, as in the case with public universities, in order to deliver intrinsically complex social goods. It is the social aspect that plays the main role in all implemented undertakings of the public sector, not the financial (commercial) one. The specificity of such an approach as compared to the commercial approach is visible in the assessment of actions undertaken by public entities ${ }^{1}$. However, this does not mean the marginalization of the importance of financial data in the assessment of their activities, which, if properly used, may enable the measurement and evaluation of actions undertaken by these entities. Moreover, one must not forget that the phenomena and processes taking place in the financial areas of these entities are often much more complex than in private sector entities. At the same time, the purpose (and therefore the main goal) of their activity is to

${ }^{1}$ S. Kasiewicz, W. Rogowski: Ocena opłacalności inwestycji społecznych. Bank i Kredyt, 2006, No. 1, 3-18. 
provide educational services at the highest possible level and to conduct scientific research. Nevertheless, it is required that, if possible, they cover the costs of their activity from the revenues they themselves generate ${ }^{2}$. However, practice shows that it is not easy to do so, and low flexibility of managing the revenue area in such public sector organizations constitutes a real challenge ${ }^{3}$. Therefore, obtaining reliable (useful for the management) information about the activities of public universities requires the use of ratios which are adequately adjusted to the specificity of their activities. This specificity results mainly from financing primarily from public funds - which is expanded in terms of its structure and complexity. This statement is supported by the literature, which draws attention to different goals of activity (compared to entities in the commercial sector), funds used to achieve these goals, and thus the method of their acquisition, spending and allocation within a given unit ${ }^{4}$.

The use of traditional financial measures (ratios) is possible because, in the light of the literature, the ratio analysis is one of the basic methods of assessing the financial condition, dedicated to public finance sector units ${ }^{5}$. However, it may turn out to be insufficient from the perspective of information needs of managers of these organizationally and legally complex entities. Moreover, focus should be put on a certain important group of these ratios, as their excess may blur the actual image of the potential of analyzed units, thus hindering making strategic and operational management decisions $^{6}$. At the same time, the review of the literature revealed a significant shortage of useful managerial knowledge about the possibility of assessing the activity of public universities. In order to fill this gap, an attempt was made to develop and define a set of ratios which would be useful from a managerial perspective, based on financial data and enabling a reliable assessment of activities of a public university. Hence, the fundamental research question that the authors have attempted to answer relates to this. The aim of this study is to answer this question, and therefore to present the results of the research work. The original set of ratios proposed by the authors is complemented by empirical verification of their measurement capacity by performing it in a specific, intentionally (due to the complexity of the analyzed data contained in many reports prepared by public universities) selected entity. The surveyed public university is a unit in which research activity and education are conducted in several separate fields of knowledge. Moreover, when making financial analyzes, comparisons in time are most often used, whereas plan comparisons and comparisons in space are the ones that are used less frequently ${ }^{7}$. On the other hand, the wider the scope of comparisons, the more complete and rich the conclusions get, becoming more capable of improving the activity

2 J. Chluska: Wynik finansowy szpitala-aspekty informacyjne i decyzyjne. Prace Naukowe Uniwersytetu Ekonomicznego we Wrocławiu, 2017, nr 471, 94-101.

${ }^{3}$ J. Chluska, A. Szewieczek: The use of cost information in the reports and financial analyzes of hospital. Prace Naukowe Uniwersytetu Ekonomicznego we Wrocławiu. 2018, No. 524, 22-34.

${ }^{4}$ Ł. Satoła: Ocena sytuacji finansowej gmin wiejskich w Polsce w latach 2006-2008. Acta Scientiarum Polonorum, Series Oeconomia, 2010, nr 9(2),199-210.

5 A. Becker, J. Becker: Zasto sowanie metody granicznej analizy danych do oceny gospodarowania województw Polski, [in:] J. Wątróbski (ed.), Studia i materiały Polskiego Stowarzyszenia Zarządzania Wiedzą, PSZW, Bydgoszcz 2009, 1-12.

${ }^{6}$ E. Mączyńska: Ocena kondycji przedsiębiorstwa, Życie Gospodarcze. 1994, No. 38.

${ }^{7}$ E. Mioduchowska-Jaroszewicz: Wskaźniki do oceny sytuacji finansowej ubezpieczycieli a porównania sektorowe, Zeszyty Teoretyczne Rachunkowości. 2012, No. 65 (121), 19-44. 
of the analyzed unit. All the more so because without comparisons, each analysis is very poor in its conclusion. For this reason, it was decided to present the results of the abovementioned test, i.e. the developed set of ratios, comparing them for the analyzed entity for the years from 2015 to 2019 . The entity was selected mainly due to the possibility of obtaining complete information contained in its statements, reports and accounting books.

\section{Research methodology}

The research activities were focused on filling the lack of knowledge, identified as a result of the literature review, regarding the existence of ratios which are reliable from the managerial point of view, and which in fact express the dynamics of economic measures of an entity, by comparing the ratios (in the case of this study) in time, creating their own set. The existing ratios commonly used to assess the financial condition of an entity were the basis of the research works directed to their development. First of all, ratios were selected which, due to the specificity of their components, can be used in the public sector (taking into account the specificity of the functioning of public universities). Then, on the basis of the results of qualitative research (a series of nonstandardized interviews with the staff managing the financial area of multi-disciplinary universities) and the experience obtained on the basis of participant observation of the authors, a set of ratios - dedicated to the assessment of the effectiveness of tasks carried out by university managers - was developed.

The developed set of ratios was defined in the areas of research, education and academic entrepreneurship. The empirical material was obtained through the use of the participant observation method taking into account direct involvement of the researcher in the activities of the studied unit. In this case, researchers interfere to some extent with the interactions between group members they are observing and their behavior ${ }^{8}$. Therefore, they enter a specific social environment, which allows them to understand the structure of the studied group better.

The use of the developed set of ratios (in the opinion of the authors, built on the basis of the results of the literature review supported by their management experience) will significantly complement the database of information on the functioning of public universities. Their construction is based on available but scattered sources of information, such as financial statements and other reports prepared by public universities. Data was also obtained from analytical records, most often coming from the university's accounting books. In the next stage of research, the authors presented examples of calculations of their set of ratios in order to evaluate a purposefully selected entity for the years from 2015 to 2019. It was established that the period of 5 years was justified for the assessment of the economic and financial position of a university, because this timeframe is indicated by legislators (LoHEaS) ${ }^{9}$ as the reference for determining the possible need for remedial actions. Constant 5-year monitoring of a university's situation is therefore necessary (also for this reason) to maintain the safe functioning of a public university.

\footnotetext{
${ }^{8}$ E. Babbie: Badania społeczne w praktyce. PWN, Warszawa 2004.

${ }^{9}$ Ustawa prawo o szkolnictwie wyższym i nauce z dnia 20 lipca 2018 r. Dz. U. 2018, poz. 1668.
} 
When developing the set of ratios, the aim was to make it of a useful nature, which means that it will be possible to successfully use the set to evaluate any public university. Due to the availability of reporting documents and detailed accounting records kept at universities, this evaluation, if necessary, will also be feasible for managers of public universities, as well as external stakeholders (obtaining information in the statutory mode of access to public information ${ }^{10}$ ).

The empirical study, with the use of the developed set of ratios, included a deliberately selected multi-disciplinary university. The criteria for its selection included the possibility of an in-depth insight into the financial and accounting areas, including financial statements and other reports prepared by public universities, as well as the fact that (as had been noticed on the basis of practical experience) the types of funding sources and the structure of tasks performed by those entities may differ to a small extent from other entities of this type and size class.

\section{The need to assess the financial condition of units in the public higher education sector}

The public higher education sector is considered complex, fragmented and turbulent. Managers of public units (including those operating within the higher education system) have to deal with many financial problems of these entities. In practice, this means that they increasingly use tools that can provide reliable information about financial processes occurring within them ${ }^{11}$. At the same time, the importance of this information is reinforced by the increase in operating costs and difficulties in obtaining the necessary resources which constitutes an unprecedented phenomenon in the functioning of public units. As a result, universities have been intensely experiencing shortages of staff, and decreases in the effectiveness of incentive systems, which, instead of resulting in the expected benefits (increased effects), only result in increasing expenditures ${ }^{12}$.

The calculation of effectiveness of all undertakings in the public sector includes the social aspect, as by definition these activities are not intended to bring financial benefits, in the meaning of commercial activities. However, all expenditures related to activities in the public sector are analyzed in terms of costs incurred and benefits obtained from their implementation ${ }^{13}$. Therefore, managers of these units are required to have more and more skills in financial management ${ }^{14}$, owing to which it will be possible to properly shape the financial phenomena occurring in them. This approach is based on the measurement and assessment of financial phenomena, which, due to their complexity,

\footnotetext{
${ }^{10}$ Pursuant to Polish legislation, in order to obtain information from a unit belonging to the public finance sector, an appropriate application must be submitted in this respect to the unit from which we want to obtain information from the resources of the public unit. Act of 6 September 2001 on access to public information (Journal of Laws of 2016, item 1764; Journal of Laws of 2017, item 933).

${ }^{11}$ K. Opolski, P. Modzelewski: Pomiar skuteczności i efektywności w urzędach administracji samorządowej podejście metodologiczne. Mazowsze Studia regionalne. Analizy i Studia, 2009, No. 2/I.

${ }^{12}$ D. Jung, C. Chow, A. Wu: The role of transformational leadership in enhancing organizational innovation: Hypotheses and some preliminary findings. The Leadership Quarterly, 2003, Vol. 14(4-5), 525- 544.

${ }^{13}$ S. Kasiewicz, W. Rogowski: Ocena opłacalności inwestycji społecznych. Bank i Kredyt, 2006, No. 1, 3-18.

14 T. Swanwick, J. McKimm: What is clinical leadership... and why is it important? The Clinical Teacher, 2011, Vol. 5(1), 22-26.
} 
require separate analytic tools, not used in the private sector - ratios informing about important phenomena and processes.

Measuring the financial condition of public sector entities is not simple. Researchers $^{15}$ even indicate that measuring financial performance of these entities is a challenge for those who work with financial information on a daily basis, and this difficulty is amplified for people who do not deal with finances ${ }^{16}$. Therefore, in order to assess the economic condition of a public university, in addition to the ratios built with the use of financial statements (prepared on the basis of legal regulations relating to the accounting of organizational units), one should obtain data from the material and financial schedule (MFS) prepared by the assessed units (in this case, public universities).

\section{The use of ratio analysis in the assessment of the financial condition of a public university sector unit - the specificity of measurement}

The ratio analysis enables a quick insight into the economic condition of a unit ${ }^{17}$. This type of analysis can be used to examine both the data contained in financial statements, other reports obligatorily prepared in public universities, as well as reports prepared optionally in these units. First of all, the analysis is the most effective one when assessing differences in relation to changes occurring in entities, presented in financial statements, and above all in the profit and loss accounts, due to the greater cause and effect relationships resulting from them ${ }^{18}$.

Traditionally, the ratio analysis was performed in order to highlight risks by comparing the relative efficiency of a client against an auditor's expectations based on the industry and/or the client's performance in previous years ${ }^{19}$.

The main problem with the traditional ratio analysis is the use of subjective weights, which are often indeterminate, as well as the auditors' choice of specific ratios to compare and assess the client's overall condition ${ }^{20}$.

Considering the assessment of the effectiveness of universities (through a specific assessment of a unit), appropriate for the sector of public universities, one should indicate products specific for the tasks they carry out (research, higher education and projects, the results of which are implemented into the economy), which go to those who value them most and are best prepared to use them. Moreover, the high effectiveness of a university's operation means that these units are able to achieve high results in all their assigned areas, i.e. in the field of education, research and economic activity. It has been

\footnotetext{
15 J.H. Burkhardt, J.R.C. Wheeler: Examining Financial Performance Indicators for Acute Care Hospitals. Journal of Health Care Finance, 2013, Vol. 39, No. 3, 1-13.

${ }_{16}$ A. Crosby, H. J. Knepper, H. Levine: Predicting hospital closure using popular financial indicators: An exploratory study of Muhlenberg Hospital. Public Administration Quarterly, 2020, Vol. 44, no. 1, 104-130.

${ }^{17}$ B. Kotowska, A. Uziębło, O. Wyszkowska-Kaniewska: Analiza finansowa w przedsiębiorstwie. CeDeWu 2021.

${ }^{18}$ L.B. Sawyer, M.A. Dittenhofer, J.H. Scheiner: Sawyers' internal auditing. The Institute of Internal Auditors, Altamonte Springs, FL, 2005, 492-503.

${ }^{19}$ A. Arens, R. Elder, M. Beasley: Auditing: An Integrated Approach. Ninth edition Englewood Cliffs, Prentice Hall, 2003.

${ }^{20}$ E.H. Feroz, S. Kim, R.L. Raab: Analytical procedures: A data envelopment analysis approach. Journal of Emerging Technologies in Accounting, 2, 2005, 17-31.
} 
a common fact for a long time - as indicated in the literature - that if an entity (in this case, a university) has more than one objective, then the assessment of their implementation may also be carried out from the perspective of the objectives in general (jointly), as well as from the perspective of some specific objective. In this case, what is assessed is the production of goods (provision of services) that correspond to social and economic needs. Therefore, in the light of scientific findings, it is justified to jointly assess the effectiveness of public units, taking both the cost (economic) approach and the non-cost (non-economic) approach, relating, for example, to the satisfaction of recipients of these services ${ }^{21}$. This, in turn, prompts the perception of the results of the undertakings implemented by these entities by the use of the cost approach.

\section{The reporting system of public universities as a source of information about their achievements/the effects of their activities}

Public universities are subject to the regime of reporting the results of activities in three areas of their operation: scientific activity, education and economic activity (mainly commercialization of results of conducted research and development works). Reports prepared by public universities include those made within the scope of external and internal financing ${ }^{22}$.

A financial statement (FS) and a statement on the implementation of the material and financial schedule (MFS) ${ }^{23}$ are the main source of information for assessing the financial condition of a public university. These statements are prepared by public universities on the basis of separate legal regulations. The analysis of financial statements, followed by their assessment, informs about the financial condition of the analyzed entity ${ }^{24}$.

The group of supplementary reports include those which (in accordance with the applicable legal regulations) inform their recipients about the effects of activities carried out in public universities, identified and conducted in three areas: research, education and entrepreneurial university activities. They are an important source of information about the position of a given university in relation to other public universities.

Table 1 contains a collection of reports that are prepared compulsorily in accordance with the areas of operation of public universities carrying out specific tasks $^{25}$, taking into account activities falling within the area of economic activity that directly implements a university's entrepreneurship ${ }^{26}$. This activity ${ }^{27}$ is carried out in

\footnotetext{
${ }^{21}$ K. Opolski, P. Modzelewski: Pomiar skuteczności i efektywności w urzędach administracji samorządowej podejście metodologiczne. Mazowsze Studia regionalne. Analizy i Studia. 2009, nr 2.

${ }^{22}$ A. Pisarska: Sources of financing tasks for public higher education institutions: findings in light of their reporting. Zeszty Naukowe SGGW w Warszawie, Polityki europejskie, finanse i marketing, 2020, nr 24(73), $155-176$.

${ }^{23}$ Art. 408. Ustawa prawo o szkolnictwie wyższym i nauce z dnia 20 lipca 2018 r. Dz. U. 2018, poz. 1668.

24 K. Bauer, M. Macuda: Sprawozdanie finansowe jako źródło informacji dla interesariuszy restrukturyzowanego szpitala. Prace naukowe Uniwersytetu Ekonomicznego we Wrocławiu, 2018, nr 503.

${ }^{25}$ Art. 350. Ustawa prawo o szkolnictwie wyższym i nauce z dnia 20 lipca 2018 r. Dz. U. 2018, poz. 1668.

${ }^{26}$ C. Barrow: The entrepreneurial University. Where it all went Wrong [in:] Transformative researchers and educators for democracy. J.M. Paraskeva, T. LaVallee (eds.), Sense Publisher, 2015, pp. 47-56; B. Dolan, J. Cunningham, M. Menter, C. McGregor: The role and function of cooperative research centers in entrepreneurial universities: A micro level perspective. Management Decision, 2019, Vol. 57, no 12, pp. 34063425 .
} 
order to commercialize research results, and the reports that are prepared in its scope result from separate regulations relating to the entities which implement them.

An important element of the reporting system of public universities is the reports presenting their financial condition, usually covering one fiscal year (Table 1), and they include: the statement on the implementation of the material and financial plan (MFS), $\mathrm{F}-01 \mathrm{~s}$, the financial statement (FS), as well as the statement on the use of subsidy obtained for a public university's operation - implemented in 2019 and reported for the first time in 2020. Public universities also provide information on the status of the settlements (receivables and liabilities), Rb-N (quarterly report on receivables and selected financial assets) and Rb-Z (quarterly statement of liabilities by title of debt), entered in their accounting books. On the other hand, the F-03 report is the report informing about the condition and changes in fixed assets of public universities.

An important group of reports are those that provide in-depth information on the value of remuneration charged in public universities (RB-70) shaping the knowledge about the position constituting the largest cost component of public universities (Table 1). Universities also prepare tax reports, e.g. PiT, CiT, VAT (Table 1).

Table 1. List of reports on the functioning of public universities

\begin{tabular}{|c|c|}
\hline \multirow{13}{*}{ 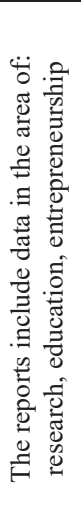 } & Financial statement (FS) \\
\hline & Statement on the implementation of the material and financial schedule (MFS) \\
\hline & Report on income, costs and financial result of universities F-01s \\
\hline & Report on the movement in fixed assets F-03 \\
\hline & $\begin{array}{l}\text { Statements and reports on the use of funds received under one subsidy for the maintenance and } \\
\text { development of didactic potential and development of research potential }\end{array}$ \\
\hline & Report on employment and remuneration RB-70 \\
\hline & Report on the status of settlements (receivables and liabilities) - Rb-N, Rb-Z \\
\hline & The Integrated System of Information on Science and Higher Education POL-on \\
\hline & Public Information Bulletin (BIP - Biuletyn Informacji Publicznej) \\
\hline & $\begin{array}{l}\text { Tax reports - incl. PiT (report on income tax from natural persons), CiT (report on direct tax from } \\
\text { enterprises), VAT }\end{array}$ \\
\hline & Reports on students and scholarships S-10, S-11, S-12 \\
\hline & $\begin{array}{l}\text { Report on the number of candidates and admissions to studies (full-time and part-time course of } \\
\text { study) EN-1 }\end{array}$ \\
\hline & Report on research and development activities PNT-01 \\
\hline
\end{tabular}

In the last few years their preparation has been undergoing constant changes, which especially concern the philosophy of building information on the basis of which data contained in the reports relating to the financial condition of the analyzed units are presented. These changes cause difficulties in interpretation and force a number of modifications, inter alia in financial and accounting IT systems. Such activities are

\footnotetext{
${ }^{27}$ Art. 149. Ustawa prawo o szkolnictwie wyższym i nauce z dnia 20 lipca 2018 r. Dz. U. 2018, poz. 1668: A university, for the purpose of indirect commercialization, consisting in taking up or acquiring shares or stocks in companies or acquiring subscription warrants entitling to subscribe or to take up shares in companies, in order to implement or prepare for implementation the results of scientific activity or know-how related to these results, may create only one-person capital companies, subject to Art. $150 \mathrm{sec}$. 1, hereinafter referred to as "special purpose entities". To cover the share capital of a special purpose entity, a university may make a contribution in kind in the form of results of scientific activity and know-how related to these results, in whole or in part. The special purpose entity is created by the Rector with the consent of the senate.
} 
associated with a large amount of workload and high additional, often unforeseen, costs incurred by universities, which further aggravates their difficult economic situation.

Public universities constantly record changes taking place in the economy of a given unit in the POL-on system, which is the most comprehensive repository of data on Polish science and higher education. Nearly 40 modules have been distinguished in it, and it is the largest operating public system in terms of the scope of collected data ${ }^{28}$. Data in the POL-on system is processed for the purpose of performing tasks related to determination and implementation of the state's scientific policy, evaluation of the quality of education, evaluation of doctoral schools and evaluation of the quality of scientific activity, conducting proceedings for the award of the doctoral degree, postdoctoral degree (doctor habilitated) and the title of a full professor, determining the amount of subsidies and subventions, supervision over the higher education and science system, implementation of tasks by the National Agency for Academic Exchange (NAWA), the National Centre for Research and Development (NCBiR) and the National Science Centre (NCN).

The group of reports prepared by universities for the Statistics Poland (Table 1) also includes those containing information about students and scholarships paid to them (S10, S-11, S-12). They are a source of information made available to the public and contain important knowledge for a researcher: on the one hand, about the condition of Polish families of students (social scholarships), and on the other hand, about the scientific potential of future generations (scientific scholarships). The EN-1 report is prepared obligatory by public universities and it refers to the number of candidates applying for studies in a given university in a given year. It contains information on the number of students enrolled in this university, divided into full-time and part-time students. On the other hand, reports on research and development activities (PNT-01) contain information on the sources of financing for all activities implementing research and development works. They inform about the amounts of expenditure incurred on various undertakings that lead to obtaining research results and their possible implementation into the economy. They are carried out with the involvement of specialized equipment and appropriate staff.

\section{Verification of the usefulness of ratios to assess the financial condition of a public university}

Table 2 contains the ratios determined as relations of selected economic categories. Sets of economic ratios, very similar in terms of content, are used in entities carrying out various, often different tasks. They may be useful for assessing the economic and financial condition of public universities ${ }^{29}$. All of them are designed to support the knowledge of the general economic condition according to established standards (developed mainly by the private sector). They are an extremely important element providing knowledge in this field.

\footnotetext{
${ }^{28}$ https://polon.nauka.gov.pl/siec-polon

${ }^{29}$ M. Sierpińska, T. Jachna: Ocena przedsiębiorstwa według standardów światowych. PWN, Warszawa 2004 $144-213$.
} 
Table 2. A set of ratios for assessing the economic and financial condition of an audited entity

\begin{tabular}{|c|c|c|c|c|c|c|c|}
\hline \multirow{2}{*}{\multicolumn{2}{|c|}{ Economic condition ratio }} & \multirow{2}{*}{ Ratio structure } & \multicolumn{5}{|c|}{ Years } \\
\hline & & & 2015 & 2016 & 2017 & 2018 & 2019 \\
\hline \multirow{4}{*}{ 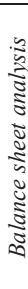 } & $\begin{array}{l}\text { Fixed assets and current } \\
\text { assets ratio } \%\end{array}$ & Fixed assets/Current assets $* 100 \%$ & 12.6 & 10.3 & 9.2 & 6.3 & 9.3 \\
\hline & $\begin{array}{l}\text { Ratio of equity capital } \\
\text { (funds) to liabilities and } \\
\text { provisions for liabilities \% }\end{array}$ & $\begin{array}{l}\text { Equity (funds)/ Liabilities and provisions } \\
\text { for liabilities } * 100 \%\end{array}$ & 2.17 & 2.42 & 2.53 & 1.94 & 2.80 \\
\hline & $\begin{array}{l}\text { The golden financing rule } \\
\%\end{array}$ & Equity (funds)/Fixed assets*100\% & 0.74 & 0.78 & 0.80 & 0.76 & 0.82 \\
\hline & The silver financing rule $\%$ & $\begin{array}{l}\text { Equity (funds) + Provisions for liabilities } \\
+ \text { Long-term liabilities/Fixed } \\
\text { assets } * 100 \%\end{array}$ & 0.97 & 0.99 & 0.99 & 1.00 & 1.03 \\
\hline \multirow{3}{*}{ 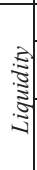 } & Current liquidity & Current assets/Short-term liabilities & 0.7 & 0.95 & 0.91 & 0.98 & 1.43 \\
\hline & Quick liquidity & $\begin{array}{l}\text { Current assets - Inventory - Short-term } \\
\text { prepayments/Short-term liabilities }\end{array}$ & 0.68 & 0.89 & 0.84 & 0.88 & 1.28 \\
\hline & Cash liquidity & $\begin{array}{l}\text { Short-term investments/Short-term } \\
\text { liabilities }\end{array}$ & 0.55 & 0.69 & 0.62 & 0.72 & 1.01 \\
\hline \multirow{9}{*}{ 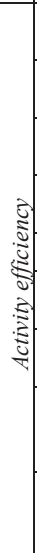 } & Inventory cycle in days & $\begin{array}{l}\text { Average inventory/Net sales } \\
\text { revenue*365 }\end{array}$ & 0.4 & 0.2 & 0.2 & 0.4 & 0.3 \\
\hline & Receivables cycle in days & $\begin{array}{l}\text { Average receivables/Net sales revenue } \\
* 365\end{array}$ & 15.0 & 18.3 & 23.0 & 25.5 & 21.1 \\
\hline & Liabilities cycle in days & $\begin{array}{l}\text { Average liabilities/Net sales revenue } \\
* 365\end{array}$ & 133.5 & 117.3 & 109.7 & 130.2 & 112.8 \\
\hline & Cash cycle & $\begin{array}{l}\text { Inventory cycle in days + Receivables } \\
\text { cycle in days + Liabilities cycle in days }\end{array}$ & -118 & -99 & -86 & -104 & -91 \\
\hline & Assets rotation & Net sales revenue /Average assets & 0.3 & 0.3 & 0.3 & 0.3 & 0.4 \\
\hline & $\begin{array}{l}\text { Rotation/productivity of } \\
\text { fixed assets }\end{array}$ & Net sales revenue /Average fixed assets & 0.3 & 0.3 & 0.4 & 0.4 & 0.4 \\
\hline & Rotation of current assets & $\begin{array}{l}\text { Net sales revenue /Average current } \\
\text { assets }\end{array}$ & 4.3 & 4.0 & 3.6 & 3.0 & 3.0 \\
\hline & Rotation of liquid assets & $\begin{array}{l}\text { Net sales revenue /Average short-term } \\
\text { receivables + Average short-term } \\
\text { investments }\end{array}$ & 4.5 & 4.2 & 3.3 & 3.5 & 4.3 \\
\hline & Productivity of fixed assets & $\begin{array}{l}\text { Net sales revenue /Average balance of } \\
\text { fixed assets }\end{array}$ & 0.46 & 0.52 & 0.54 & 0.58 & 0.61 \\
\hline \multirow{6}{*}{ 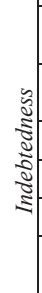 } & Total debt $\%$ & $\begin{array}{l}\text { Liabilities and provisions for liabilities } \\
/ \text { Total assets* } 100 \%\end{array}$ & 0.32 & 0.29 & 0.28 & 0.34 & 0.26 \\
\hline & Equity debt \% & $\begin{array}{l}\text { Liabilities and provisions for liabilities } \\
\text { /Equity (funds)* } 100 \%\end{array}$ & 0.46 & 0.41 & 0.40 & 0.51 & 0.36 \\
\hline & Long-term debt & Long-term liabilities/ Equity (funds)* & 0.02 & 0.01 & 0.01 & 0.01 & 0.05 \\
\hline & Coverage of debt service I & Gross result + Interest/Interest & 8.6 & 11.0 & 19.5 & 2.1 & 79.7 \\
\hline & Coverage of debt service II & Net result/Interest & 7.6 & 9.9 & 18.5 & 0.8 & 78.7 \\
\hline & $\begin{array}{l}\text { Coverage of interest } \\
\text { liabilities }\end{array}$ & Gross result + Interest/Interest & 8.6 & 11.0 & 19.5 & 2.1 & 79.7 \\
\hline
\end{tabular}

Source: authors' own study.

It can be stated that the economic and financial situation of this entity changed in many areas disclosed in its financial statements in the years from 2015 to 2019. The basic ratio of the balance sheet structure decreased gradually, which in the case of this entity means increasing the share of current assets (or decreasing the value of fixed assets) in the total assets. The basic ratio of the liabilities structure of this university was, in turn, relatively constant and it meant a relatively high (characteristically for public universities) but decreasing share of liabilities and provisions in relation to its funds. The ratio of the fund to liabilities and provisions in the analyzed period was from $2.18 \%$ in 2015 , and in 2019 it equaled $2.80 \%$. The golden and silver financing rule must also be 
considered by taking into account the specificity of financing and depreciation of buildings and structures of public universities ${ }^{30}$.

In light of the literature on the subject, the key aspect of financial management of an entity is its financial liquidity. It affects the financial comfort of a unit's functioning, its credibility towards other people and entities cooperating with it.

Financial liquidity ratios determined using the data contained in the financial statements of the examined university for the years from 2015 to 2019 allowed to state that the entity had periodic financial problems demonstrated by the determined liquidity ratios. Their low levels (below 1) in the period of 2015-2018 indicate the risk loss of financial balance, while their excessively high ratios established for 2019 inform about undeveloped surplus cash. Keeping the financial liquidity ratios too high or too low creates an unfavorable situation for them and requires an in-depth analysis of this process in each single case.

The group of ratios informing about the efficiency of an analyzed unit provides its managers with knowledge about the activity of using the unit's resources, and this in turn determines the effectiveness related to the use of a given group of the unit's assets. Cycles of various assets depend on their size and the impact they have on revenues of an analyzed unit, in relation to inventories. Universities usually maintain only small amounts of inventories, which mostly result from their research and education in specific fields of science. They mainly consist of reagents, books or other - characteristic for a given field of science - ingredients purchased as inventory (stored).

With regard to receivables, their amount results primarily from unpaid amounts due for rendered services or tuition fees. Tuition fees are charged periodically, their amount is determined by calculation, which is part of contracts concluded with students and participants of postgraduate studies or other forms of education provided by universities. The size of liabilities and their relation to revenues depends on the owned cash resources, i.e. directly on the level of the cash liquidity ratio of an entity.

Debt assessment is an extremely important problem, especially crucial for the effective management of any organizational unit. In recent years, it has become an important and actively observed area of university financial management for universities as well, mainly due to the fact that these units, when implementing investment projects (their external financing was usually insufficient or it was realized in a previously strictly defined part), require funding from other sectors, including e.g. the banking sector (Table 2). As a result, managers of universities, when trying to carry out a given investment task, are forced to indebt these units or sell (dispose of) other real estate unused at a given time. From this point of view, it becomes extremely important to observe the degree of their debt and the ability to service loans taken out in different terms of office. The group of debt ratios was determined in the audited entity by taking

\footnotetext{
${ }^{30}$ Obligatorily in all these units, fixed assets classified as land and objects of museum value and buildings are not subject to depreciation. Buildings in public higher education institutions are subject only to accumulated depreciation and parallel reduction of the value of the basic fund. At the same time, it is worth adding that the justification for just such a solution does not find full substantive support in the literature on the subject. Therefore, it can only be assumed that the adoption of this type of records was dictated by the fact that their acquisition is financed by targeted subsidies from public funds; Pisarska A: Sources of financing tasks for public higher education institutions: findings in light of their reporting. Zeszty Naukowe SGGW w Warszawie, Polityki europejskie, finanse i marketing, 2020, nr 24(73).
} 
into account its liabilities and provisions for liabilities, resulting from legal regulations applicable to public universities. Provisions for retirement benefits for employees of these units are a special group of provisions.

The debt of public universities consists of long and short-term liabilities, the largest amount of which are usually the liabilities to banks. In the studied university, the debt ratios prove high ability of universities to pay their liabilities. The total debt ratio ranged from 0.26 in 2019 to 0.32 in 2015 and it was a decreasing trend, except for 2018, when the ratio was 0.34 . The equity debt ratio in 2015 was 0.46 and decreased in each of the analyzed years to 0.36 in 2019 . Also in this case, in 2018 this ratio increased to 0.51 . The long-term debt ratio was between 0.02 and 0.05 in the analyzed period, and the increase in this ratio results from the long-term debt of the studied university in 2019. The debt coverage ratios indicate the high ability of the unit in this regard. The literature accepts the level of 1.3 as the minimum level of the debt coverage ratio I, and as its optimal level - 2.5. The debt coverage ratio II should be greater than or at least equal to 1 . During all the years of the analyzed public university there were no difficulties with debt coverage (Table 2) with the exception of 2018, when all debt coverage ratios were at risky levels from the point of view of this entity's finances.

Table 3 presents ratios suggested as the most useful for assessing the research potential (scientific activity) of employees of the public university under study. The ratios constructed according to the indicated rules will allow to verify the achievements of the research-didactic and research staff in the scope of the implementation of tasks facing the academic staff of the university. These ratios will make it possible to evaluate the use of the research potential the unit possesses, i.e. in fact the intensity and value of research works carried out by the research-didactic and research staff. In the case of the university under study, an insight into this area reveals the relatively constant level of research activity of its employees (working in the field of science) financed with external funds.

Table 3. A set of recommended ratios for evaluating the results of the functioning of public universities in the field of scientific activity

\begin{tabular}{|c|c|c|c|c|c|c|c|}
\hline \multirow{2}{*}{\multicolumn{2}{|c|}{ Scientific activity ratios }} & \multirow{2}{*}{ Ratio structure } & \multicolumn{5}{|c|}{ Years } \\
\hline & & & 2015 & 2016 & 2017 & 2018 & 2019 \\
\hline$\approx$ & $\begin{array}{l}\text { Effectiveness of obtaining } \\
\text { research grants by academic } \\
\text { teachers }\end{array}$ & $\begin{array}{l}\text { Number of grants / Average } \\
\text { number of research-didactic staff }\end{array}$ & 0.01 & 0.01 & 0.01 & 0.01 & 0.01 \\
\hline 害 & $\begin{array}{l}\text { Productivity of obtaining } \\
\text { research grants by academic } \\
\text { teachers (in PLN) }\end{array}$ & $\begin{array}{l}\text { Grant income / Average number } \\
\text { of academic teachers }\end{array}$ & 1965.2 & 4781.0 & 3480.1 & 4588.5 & 19529.5 \\
\hline 音 & $\begin{array}{l}\text { Technical equipment for } \\
\text { employees who are teachers (in } \\
\text { PLN) }\end{array}$ & $\begin{array}{l}\text { Value of research equipment / } \\
\text { Average number of academic } \\
\text { teachers }\end{array}$ & 516.36 & 435.40 & 353.76 & 282.85 & 206.67 \\
\hline & $\begin{array}{l}\text { Productivity of research } \\
\text { equipment (in PLN) }\end{array}$ & $\begin{array}{l}\text { Grant income / Value of research } \\
\text { equipment }\end{array}$ & 5.92 & 17.96 & 16.01 & 27.13 & 157.37 \\
\hline
\end{tabular}

Source: authors' own study.

The scientists carrying out their tasks at the studied university show increasing scientific activity, which is evidenced mainly by the ratio of productivity of academic teachers due to obtained grants, which increased each year. The increase in revenues from grants per 1 academic teacher should be assessed positively. The number of grants is taken into account in the subsidy distribution algorithm, positively influencing its 
amount. The ratio of technical equipment in the work of academic teachers informs about the value of research equipment per one employee in this area. Research equipment ${ }^{31}$ is purchased primarily with the use of the sources from publicly funded projects, coming from National Science Centre (NCN) grants or funds allocated to research financed from the European Union budget. At the same time, the most important funds for university managers are those that have the greatest impact on the amount of the subsidy allocated from the Ministry of Education and Science, and therefore those that have the highest importance in the distribution algorithm.

The obtained values of ratios are characterized by high managerial utility. They can help the university authorities determine the incentives for employees to undertake more intensified scientific activity. When analyzing this area of university operation, one should take into account the influence of the examined segment of the activities of a public university (in this case, the area of science) on the distribution algorithm of the subsidy financing the activities of a public university, e.g. in the field of science.

Table 4 presents ratios useful in determining the didactic potential (didactic activity). They will make it possible to evaluate the activities carried out by universities in the field of education of, primarily, students, doctoral students and postgraduate students, which is associated with improving the quality of education. The set of these ratios includes many aspects taken into account when assessing this area of university operation. The variables taken into consideration when analyzing the area of education include, first of all, the number of academic teachers, the number of administrative employees, the number of fields of study, the number of students, revenues relating to this area, costs resulting from the implementation of tasks in this area, as well as the value of university resources used in this area (including fixed assets). The number of academic teachers per field of study conducted at the university informs about the positions within those fields taken by academic teachers employed at the university under analysis. This ratio may be important for assessing the quality of education at the university under study. It may be of interest to future students, university accreditation committees and external stakeholders.

The ratio informing about the number of administrative employees assigned to the number of fields of study realized at a given university can be treated as complementary to the previous one. It indicates the commitment of university managers to the implemented tasks and improving the quality of student service. The number of students per one field of study, per the number of academic teachers and the number of administrative employees indicates primarily the perception of the university as an organization in which students can pursue and develop their talents. The chosen university is assessed by them as the one with an attractive educational offer.

The operating costs and general and administrative costs were established in reference to one student, academic teacher and administrative employee. On the other hand, the cost of remuneration was determined in relation to the number of teachers and administrative employees.

\footnotetext{
${ }^{31}$ Scientific and research equipment are sets of research, measuring or laboratory devices with a low degree of versatility and high technical parameters (usually higher by several orders of measurement accuracy than typical equipment used for production or operational purposes). Additional methodological explanations: the scientific and research equipment does not include computer equipment and other devices not used directly for the implementation of R\&D works, Statistics Poland, Warsaw.
} 
Table 4. A set of recommended indicators for the evaluation of the results of the functioning of public universities in terms of didactic activity

\begin{tabular}{|c|c|c|c|c|c|c|}
\hline \multirow{2}{*}{ Didactic activity ratios } & \multirow{2}{*}{ Ratio structure } & \multicolumn{5}{|c|}{ Years } \\
\hline & & 2015 & 2016 & 2017 & 2018 & 2019 \\
\hline $\begin{array}{l}\text { Teaching staff in the } \\
\text { fields of study } \\
\text { implemented }\end{array}$ & $\begin{array}{l}\text { Average number of academic } \\
\text { teachers / number of fields of } \\
\text { study }\end{array}$ & 7.3 & 7.0 & 6.3 & 6.2 & 5.4 \\
\hline $\begin{array}{l}\text { Operational } \\
\text { administrative staff in } \\
\text { the field of studies } \\
\text { implemented }\end{array}$ & $\begin{array}{l}\text { Average number of } \\
\text { administrative employees / } \\
\text { number of fields of study }\end{array}$ & 4.6 & 4.3 & 3.8 & 3.7 & 3.3 \\
\hline $\begin{array}{l}\text { Attractiveness of the } \\
\text { didactic offer }\end{array}$ & $\begin{array}{l}\text { Number of students / Number of } \\
\text { fields of study }\end{array}$ & 100.3 & 90.3 & 81.6 & 77.6 & 65.8 \\
\hline $\begin{array}{l}\text { Didactic effectiveness } \\
\text { of academic teachers }\end{array}$ & $\begin{array}{l}\text { Number of students / average } \\
\text { number of academic teachers }\end{array}$ & 13.7 & 12.9 & 13.0 & 12.5 & 12.2 \\
\hline $\begin{array}{l}\text { Effectiveness of } \\
\text { administrative } \\
\text { employees }\end{array}$ & $\begin{array}{l}\text { Number of students / average } \\
\text { number of administrative } \\
\text { employees }\end{array}$ & 22.0 & 21.1 & 21.6 & 20.9 & 19.9 \\
\hline $\begin{array}{l}\text { Productivity of } \\
\text { academic teachers (in } \\
\text { PLN) }\end{array}$ & $\begin{array}{l}\text { Operating income / average } \\
\text { number of academic teachers }\end{array}$ & 161669.1 & 163441.3 & 170596.4 & 172720.3 & 215456.1 \\
\hline $\begin{array}{l}\text { Productivity of } \\
\text { administrative } \\
\text { employees (in PLN) }\end{array}$ & $\begin{array}{l}\text { Operating income / average } \\
\text { number of administrative } \\
\text { employees }\end{array}$ & 259034.5 & 266892.9 & 282377.7 & 289958.8 & 352086.8 \\
\hline $\begin{array}{l}\text { Education } \\
\text { productivity (in PLN) }\end{array}$ & $\begin{array}{l}\text { Operating income / total average } \\
\text { number of students }\end{array}$ & 11769.3 & 12624.8 & 13074.2 & 13860.6 & 17717.4 \\
\hline $\begin{array}{l}\text { Average total cost per } \\
1 \text { academic teacher } \\
\text { (in PLN) }\end{array}$ & $\begin{array}{l}\text { Operating costs / average } \\
\text { number of academic teachers }\end{array}$ & 183703.3 & 179436.8 & 182894.1 & 186536.0 & 208902.4 \\
\hline $\begin{array}{l}\text { Average total cost per } \\
1 \text { administrative } \\
\text { employee (in PLN) }\end{array}$ & $\begin{array}{l}\text { Operating costs / average } \\
\text { number of administrative } \\
\text { employees }\end{array}$ & 294338.8 & 293012.9 & 302733.2 & 313152.2 & 341377.1 \\
\hline $\begin{array}{l}\text { Average total cost per } \\
1 \text { student (in PLN) }\end{array}$ & $\begin{array}{l}\text { Operating costs / average } \\
\text { number of students }\end{array}$ & 13373.3 & 13860.3 & 14016.7 & 14969.3 & 17178.4 \\
\hline $\begin{array}{l}\text { Average general and } \\
\text { administrative costs } \\
\text { per } 1 \text { academic } \\
\text { teacher (in PLN) } \\
\end{array}$ & $\begin{array}{l}\text { General and administrative costs } \\
\text { / average number of academic } \\
\text { teachers }\end{array}$ & 25074.5 & 26098.9 & 27098.9 & 30379.7 & 37551.7 \\
\hline $\begin{array}{l}\text { Average general and } \\
\text { administrative costs } \\
\text { per } 1 \text { administrative } \\
\text { employee (in PLN) }\end{array}$ & $\begin{array}{l}\text { General and administrative costs } \\
\text { / average number of } \\
\text { administrative employees }\end{array}$ & 40175.7 & 42618.4 & 44855.2 & 51000.7 & 61365.0 \\
\hline $\begin{array}{l}\text { Average general and } \\
\text { administrative costs } \\
\text { per } 1 \text { student (in } \\
\text { PLN) }\end{array}$ & $\begin{array}{l}\text { General and administrative costs } \\
\text { / average number of students }\end{array}$ & 1825.4 & 2016.0 & 2076.8 & 2437.9 & 3087.9 \\
\hline $\begin{array}{l}\text { Average salary of an } \\
\text { academic teacher per } \\
1 \text { student (in PLN) }\end{array}$ & $\begin{array}{l}\text { Teachers' remuneration / } \\
\text { average number of students }\end{array}$ & 5.7 & 6.0 & 6.0 & 6.4 & 7.3 \\
\hline $\begin{array}{l}\text { Average salary of an } \\
\text { administrative } \\
\text { employee per } 1 \\
\text { student (in PLN) }\end{array}$ & $\begin{array}{l}\text { Remunerations of administrative } \\
\text { employees / average number of } \\
\text { students }\end{array}$ & 2.0 & 2.0 & 2.1 & 2.3 & 2.7 \\
\hline $\begin{array}{l}\text { Technical equipment } \\
\text { of academic teachers } \\
\text { (in PLN) }\end{array}$ & $\begin{array}{l}\text { Value of fixed assets / average } \\
\text { number of academic teachers }\end{array}$ & 375283.5 & 344253.7 & 326191.7 & 310853.3 & 347319.8 \\
\hline $\begin{array}{l}\text { Technical equipment } \\
\text { of students (in PLN) }\end{array}$ & $\begin{array}{l}\text { Value of fixed assets / average } \\
\text { total number of students }\end{array}$ & 27320.1 & 26591.3 & 24998.7 & 24945.5 & 28560.8 \\
\hline
\end{tabular}

Source: authors' own study.

Fixed assets are an important item in the entity's assets. Their value was assigned to the number of teachers, administrative employees and students. The ratios established 
according to this method present the value of fixed assets that is used by students and employees while studying and carrying out education, as well as conducting scientific research.

Some of these parameters already have their own standards, e.g. the number of students per one academic teacher has the $\mathrm{SSR}^{32}$, while the number of students per one field of study may indicate obligatory or optional limits set within the unit.

Table 5 contains ratios of entrepreneurial activity (academic entrepreneurship), which currently (in accordance with current legal regulations) is an important aspect of public university management. Ratios constructed according to the presented rules will allow to verify the achievements of academic teachers in the scope of their entrepreneurial activity. This is all the more important because, as researchers point out, university scientists traditionally focus on basic research, and most of them have no practical experience in the field of entrepreneurship, and therefore they may not consider critical issues related to their ventures ${ }^{33}$.

Table 5. A set of ratios to assess the performance of public universities in terms of their economic activity

\begin{tabular}{|c|c|c|c|c|c|c|c|}
\hline & \multirow{2}{*}{ Economic activity ratios } & \multirow{2}{*}{ Ratio structure } & \multicolumn{5}{|c|}{ Years } \\
\hline & & & 2015 & 2016 & 2017 & 2018 & 2019 \\
\hline \multirow{4}{*}{ 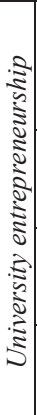 } & $\begin{array}{l}\text { Productivity of academic } \\
\text { teachers in terms of } \\
\text { implementation works (in } \\
\text { PLN) }\end{array}$ & $\begin{array}{l}\text { Revenues from sales of } \\
\text { implementation works / } \\
\text { Average number of } \\
\text { teachers }\end{array}$ & 732.5 & 359.4 & 279.7 & 504.6 & 876.4 \\
\hline & $\begin{array}{l}\text { Profitability of economic } \\
\text { activities carried out by } \\
\text { academic teachers (in PLN) }\end{array}$ & $\begin{array}{l}\text { Revenues from } \\
\text { implemented projects / } \\
\text { Number of projects }\end{array}$ & 0.0 & 0.0 & 0.0 & 0.0 & -876.0 \\
\hline & $\begin{array}{l}\text { Profitability of business units } \\
\%\end{array}$ & $\begin{array}{l}\text { Profit (loss) of business } \\
\text { entities / Sales revenues } \\
\text { x } 100 \%\end{array}$ & 0.0 & 0.0 & 0.0 & 0.0 & 0.0 \\
\hline & $\begin{array}{l}\text { Productivity of research staff } \\
\text { in business entities (in PLN) }\end{array}$ & $\begin{array}{l}\text { Total revenues in business } \\
\text { units / Average number of } \\
\text { research staff }\end{array}$ & 0.0 & 0.0 & 0.0 & 0.0 & 0.0 \\
\hline
\end{tabular}

Source: authors' own study.

The ratios in Table 5 revealed the problem of the studied university in terms of employee activity in relation to the commercialization of scientific research results and the dissemination of scientific achievements. This area requires special care on the part of university managers and their employees due to the fact that the effective operation of academic teachers has an impact on the financing and evaluation of public universities.

${ }^{32}$ The number of students per one academic teacher at the i-th public academic university, which determines the ratio of staff to students.

${ }^{33}$ K. Bischoff, C.K. Volkmann, D.B. Audretsch: Stakeholder Collaboration in Entrepreneurship Education: An Analysis of the Entrepreneurial Ecosystems of European Higher Educational Institutions. Journal of Technology Transfer, 2018, Vol. 43, No 1, pp. 20-46; C. O’kane, , V. Mangematin, W. Geoghegan, C. Fitzgerald: University Technology Transfer Offices: The Search for Identity to Build Legitimacy. Research Policy, 2015, Vol. 44, No 2, pp. 421-437; R-M. Hsieh, D. Kelley: A Study of Key Indicators of Development for University-Based Entrepreneurship Ecosystems in Taiwan, Entrepreneurship Research Journal, 2020 , Vol. 10, No 2, pp. 1-17. 
The activities of universities in this area influence the amount of obtained subsidies in direct and indirect ways. In this field, universities may also conduct business activities, which will affect the amount of revenues increasing the inflowing cash, or they may conduct separate economic activities (e.g. in the form of special purpose entities). However, the economic and financial effectiveness of these activities can be assessed using a standard set of ratios.

\section{Conclusions}

In line with the concept of an entrepreneurial university, the set of activities implemented by universities covers three coexisting areas: science, education and entrepreneurship. Hence, in order to assess the performance of a university, it is necessary to measure the effects it achieves in all of these dimensions. The obtained results play an important role, particularly in view of being able to ensure the effective functioning of a public university.

Noting the existing tool shortage in this respect, the study proposes a set of ratios which are most useful for managing a public university, which fully reflect the situation of such a unit. At the same time, an attempt was made to present their informative usefulness on a specific example. The data used was obtained from the financial statements and accounting records of the analyzed entity for the years from 2015 to 2019. It was established that the period of 5 years was justified for the assessment of the economic and financial condition of the university, as the five-year time interval is used to determine the need to carry out corrective actions. The obligation of implementing such actions results from the $\mathrm{LoHEaS}^{34}$. Constant 5-year monitoring of a university's financial situation is therefore (also for this reason) necessary to maintain a safe and developmental position of this university.

Research conducted at a deliberately selected multi-discipline university allowed for its evaluation over time. In the period of 2015-2019, this unit changed in the analyzed areas, which is indicated by the respective increase or decrease in the size of the ratios. For example, the fixed assets and current assets ratio (it decreased in the analyzed period) proves the low flexibility (possibility of liquidation) of assets, which implies a high degree of relevance to the particularities of the unit under review. On the other hand, the value of financial liquidity ratios in the audited period showed that the university had periodic problems with financial liquidity. The low levels of these ratios in the years from 2015 to 2018 indicate the risk of losing financial balance, while too high ratios determined for 2019 inform about undeveloped cash surpluses.

It should be borne in mind that an important feature of the proposed ratios is taking into account the specificity of financing, including depreciation of buildings and structures of public universities, and, above all, the tasks these units carry out in the field of research, commercialization of research results and education.

The presented concept should be treated as a voice in the discussion on the possibility of shaping the effectiveness of these characteristic units such as universities. At the same time, the authors take into account the limitations of the presented concept of measurement, which results from its versification in one entity only. Conducting

${ }^{34}$ Art. 418. Ustawa prawo o szkolnictwie wyższym i nauce z dnia 20 lipca 2018 r. Dz. U. 2018, poz. 1668. 
further research on a wider group of units may confirm or contribute to the correction of the findings made in this matter.

In the perspective of further research, the relativisation of the ratio values in relation to a group of public universities, or to all of them in general, will allow to determine whether the ratio values are high or low. Moreover, their interpretation in relation to the functioning of other entities in the sector will allow to develop standards in a given scope. It should be assumed that they will differ in relation to different groups of universities (universities, universities of technology, economic universities, agricultural universities, pedagogical universities, physical education universities, music universities, medical universities etc.).

At the same time, when assessing the effectiveness of public universities on the basis of financial ratios, one should take into account their specificity resulting from the size of the activities they realize in some of their groups, which is related to the tasks they carry out, the specificity of using certain groups of assets and the origin of funds that finance them.

\section{References}

Arens A., Elder R., Beasley M.: Auditing: An Integrated Approach. Ninth edition Englewood Cliffs, Prentice Hall 2003.

Babbie E.: Badania społeczne w praktyce. PWN, Warszawa 2004.

Barrow C.: The entrepreneurial University. Where it all went Wrong [in:] Transformative researchers and educators for democracy. J.M. Paraskeva, T. LaVallee (eds.), Sense Publisher, 2015.

Bauer K., Macuda M.: Sprawozdanie finansowe jako źródło informacji dla interesariuszy restrukturyzowanego szpitala. Prace naukowe Uniwersytetu Ekonomicznego we Wrocławiu, 2018, Nr. 503.

Becker A., Becker J.: Zastosowanie metody granicznej analizy danych do oceny gospodarowania województw Polski, [in:] Wątróbski J. (ed.), Studia i materiały Polskiego Stowarzyszenia Zarządzania Wiedzą, PSZW, Bydgoszcz 2009.

Bischoff K., Volkmann C.K., Audretsch D.B.: Stakeholder Collaboration in Entrepreneurship Education: An Analysis of the Entrepreneurial Ecosystems of European Higher Educational Institutions. Journal of Technology Transfer, 2018, Vol. 43, No 1.

Burkhardt J.H., Wheeler J.R.C.: Examining Financial Performance Indicators for Acute Care Hospitals. Journal of Health Care Finance, 2013, Vol. 39, No. 3.

Chluska J., Szewieczek A.: The use of cost information in the reports and financial analyzes of hospital. Prace Naukowe Uniwersytetu Ekonomicznego we Wrocławiu. 2018, No. 524.

Chluska J.: Wynik finansowy szpitala-aspekty informacyjne i decyzyjne. Prace Naukowe Uniwersytetu Ekonomicznego we Wrocławiu, 2017, nr 471.

Crosby A., Knepper H. J., Levine H.: Predicting hospital closure using popular financial indicators: An exploratory study of Muhlenberg Hospital. Public Administration Quarterly, 2020, Vol. 44, no. 1.

Dolan B., Cunningham J., Menter M., McGregor C. The role and function of cooperative research centers in entrepreneurial universities: A micro level perspective. Management Decision, 2019, Vol. 57, no 12.

Feroz E.H., Kim S., Raab R.L.: Analytical procedures: A data envelopment analysis approach. Journal of Emerging Technologies in Accounting, 2005, Vol. 2.

Hsieh R-M., Kelley D.: A Study of Key Indicators of Development for University-Based Entrepreneurship Ecosystems in Taiwan, Entrepreneurship Research Journal, 2020, Vol. 10, No 2. 
Jung D., Chow C., Wu A.: The role of transformational leadership in enhancing organizational innovation: Hypotheses and some preliminary findings. The Leadership Quarterly, 2003, Vol. 14(4-5).

Kasiewicz S., Rogowski W.: Ocena opłacalności inwestycji społecznych. Bank i Kredyt, 2006, No. 1.

Kotowska B., Uziębło A., Wyszkowska-Kaniewska O.: Analiza finansowa w przedsiębiorstwie. CeDeWu 2021.

Mączyńska E.: Ocena kondycji przedsiębiorstwa, Życie Gospodarcze. 1994, No. 38.

Mioduchowska-Jaroszewicz E.: Wskaźniki do oceny sytuacji finansowej ubezpieczycieli a porównania sektorowe, Zeszyty Teoretyczne Rachunkowości. 2012, No. 65 (121).

O'kane C., Mangematin V., Geoghegan W., Fitzgerald C.: University Technology Transfer Offices: The Search for Identity to Build Legitimacy. Research Policy, 2015, Vol. 44, No 2.

Opolski K., Modzelewski P.: Pomiar skuteczności i efektywności w urzędach administracji samorządowej - podejście metodologiczne. Mazowsze Studia regionalne. Analizy i Studia, 2009, No. 2/I

Pisarska A.: Sources of financing tasks for public higher education institutions: findings in light of their reporting. Zeszty Naukowe SGGW w Warszawie, Polityki europejskie, finanse i marketing, 2020, $\mathrm{nr} 24(73)$.

Satoła Ł.: Ocena sytuacji finansowej gmin wiejskich w Polsce w latach 2006-2008. Acta Scientiarum Polonorum, Series Oeconomia, 2010, nr 9(2).

Sawyer L.B., Dittenhofer M.A., Scheiner J.H.: Sawyers' internal auditing. The Institute of Internal Auditors, Altamonte Springs, FL, 2005.

Sierpińska M., Jachna T.: Ocena przedsiębiorstwa według standardów światowych, PWN, Warszawa 2004.

Swanwick T., McKimm J.: What is clinical leadership....and why is it important? The Clinical Teacher, 2011, Vol. 5(1).

Ustawa prawo o szkolnictwie wyższym i nauce z dnia 20 lipca 2018 r. Dz. U. 2018, poz. 1668.

\section{Wyniki funkcjonowania uczelni publicznych: ustalenie zestawu wskaźników zapewniających wiarygodną informację zarządezą w oparciu o dane pochodzące ze sprawozdań jednostki}

\section{Streszczenie}

Celem opracowania jest określenie zestawu wskaźników umożliwiających wielowymiarową ocenę działalności publicznych szkół wyższej jako jednostek sektora finansów publicznych w celu usprawnienia efektywności zarządzania nimi. Dobór właściwych, odznaczających się wysoką wiarygodnością o zachodzących w nich zjawiskach i procesach wskaźników staje się przydatnym narzędziem zarządczym. Stąd też w treści opracowania dokonano kompleksowego pomiaru wyników uczelni. Badania empiryczne przeprowadzono na celowo dobranym uniwersytecie wielodziedzinowym, czyli podmiocie prowadzącym działalność badawczą i dydaktyczną w obszarze wielu dziedzin nauki. Materiał empiryczny zgromadzono przy wykorzystaniu informacji pochodzących ze sprawozdań finansowych i informacji analitycznych pochodzących z ksiąg rachunkowych badanej jednostki. Badaniem objęto lata 20015-2019. Przeprowadzone badania empiryczne dostarczyły argumentów, w świetle których opracowany zestaw wskaźników posiada wysoką użyteczność zarządczą, gdyż pozwolił ocenić stan zachodzących w badanej jednostce zjawisk. 
Słowa kluczowe: efektywność szkół wyższych, przedsiębiorczość, kształcenie, badania naukowe, sprawozdawczość, sektor publiczny

JEL Codes: I23; M41; M49

Information about the authors:

Dr Aleksandra Pisarska

Prof. dr hab. Jarosław Karpacz

Jan Kochanowski University of Kielce

ul. Uniwersytecka 15, 25-406 Kielce, Polska

e-mail: aleksandra.pisarska@ujk.edu.pl

ORCID: 0000-0002-8165-0691

e-mail: jaroslaw.karpacz@ujk.edu.pl

ORCID: 0000-0001-7315-2855 